\title{
Students set up forum to debate hot topics
}

Jonathan Knight, Seattle

Graduate students at the University of Washington in Seattle are leading an initiative to encourage dialogue between scientists and the public on hot research issues.

Five biology students at the university set up the Forum on Science Ethics and Policy (FOSEP), which aims to stir up public discussion on areas of research that raise ethical concerns, such as human embryonic stemcell research.

The forum will hold its first major public meeting - in a hall that seats an audience of 700 - on 18 October, when a panel of scientists will discuss stem-cell research. The meeting falls just before the presidential election, in which stem cells have emerged as an important issue.

Melanie Roberts, a neurobiology graduate student and one of FOSEP's co-founders, says the project sprang from concern that there weren't enough opportunities for scientists and the general public to exchange views on the controversial issues surrounding research, from genetically engineered crops to nanotechnology.

In January, she teamed up with four other policy-minded classmates to start FOSEP. They contacted numerous experts for advice, raised funds, drew up a budget and scheduled events.

FOSEP has an unconventional goal. Whereas other public outreach efforts tend to emphasize science education for a lay audience, FOSEP is intended as much for the benefit of scientists, who may have a limited grasp of how the public sees their work.

"We don't want to talk about educating the public," says Roberts. "We are not promoting a particular position. We want to provide a forum for the public and the scientists to communicate."

Matt Zonarich, national coordinator for

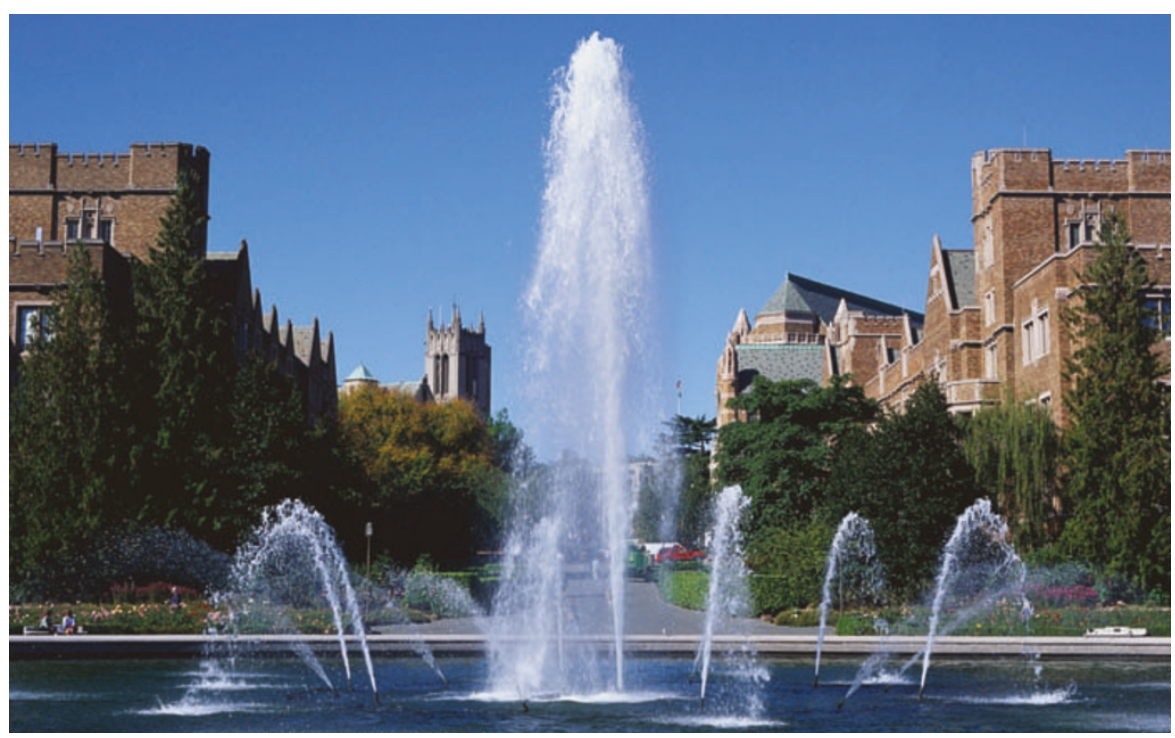

Fount of knowledge: students at the University of Washington want to inspire public discussion.

the Joint Steering Committee for Public Policy, a biomedical research advocacy group based in Washington DC, notes how unusual this is. "I've been doing grassroots biomedical research advocacy for almost four years, and I have yet to come across another effort with the same mission," he says.

The October event, which is being promoted through local newspapers and radio shows, will include a panel of two stem-cell researchers, a bioethicist and an expert on health policy. For most of the evening the panel will respond to questions from the audience, moderated by Seattle public radio host Ross Reynolds. A web-cast will be available and the speakers will continue to answer questions online after the event.

Research policy experts welcome the forum approach. "Roberts and others are thinking that maybe not all scientific research is good, or should be done," says
Jane Maienschein, director of the Center for Biology and Society at Arizona State University in Tempe. "They are learning to be more sympathetic to competing views." Maienschein gave a FOSEP-sponsored public lecture in May.

The intention is to hold at least one forum a year, Roberts says. As the founding members of FOSEP graduate - Roberts intends to finish in May - they will be replaced by younger students. To make the organization sustainable in the face of student turnover, FOSEP is applying for grants and drawing up a permanent organizational structure.

Roberts says she was initially concerned that no one would take a student group seriously. But as it turns out, FOSEP's student leadership has been an asset. "I think a lot of people have opened their doors to us as graduate students who might not have for faculty," she says.

\section{Research plane will scale uncharted heights}

\section{Quirin Schiermeier, Munich}

The German research ministry has approved the construction of a high-performance research aircraft that should be ferrying European atmospheric researchers into the upper atmosphere by 2007.

The $€ 67-$ million (US\$81.5-million) High Altitude and Long Range Research Aircraft (HALO) will be able to fly 8,000 kilometres before refuelling, allowing scientists to monitor conditions in some of the crucial regions for climate research around the world - from Brazil to the South Atlantic, and from southeast Asia to arctic Russia. Its maximum payload of more than 3 tonnes will enable several groups to conduct experiments simultaneously during one flight.

The plane is designed to reach unprecedented heights of 16,000 metres the upper part of the boundary region between the stratosphere and the troposphere. Other research planes can reach only a maximum of 13,000 metres. Studying this higher region will improve researchers' understanding of atmospheric circulation. It will also help them to evaluate whether pollution from the growing fleet of commercial aircraft is having an impact on cloud formation and climate.

HALO will be based on a Gulfstream
G550 - a luxury passenger jet. But its interior will bear little resemblance to its plush origins. The seats will be replaced by two rows of cabin-high instrument racks, with small niches for up to six operators. A window in the plane's floor will allow observation of the atmosphere below.

The United States also has a highspecification research plane in the works. Its High-performance Instrumented Airborne Platform for Environmental Research (HIAPER), commissioned three years ago, is due to fly its first missions next year. But the German plane is based on a newer, larger jet. 